\title{
WYKORZYSTANIE DANYCH TEKSTOWYCH DO MONITOROWANIA NASTROJÓW I SPOSOBU POSTRZEGANIA MARKI NA PRZYKŁADZIE PORTALI SPOŁECZNOŚCIOWYCH
}

Z a r y s t r e ś c i: W artykule wykorzystano technikę text mining do ekstrakcji informacji z danych tekstowych w celu wykorzystania ich na potrzeby zarządzania wizerunkiem marki. Podstawowym celem niniejszego opracowania jest prezentacja eksploracyjnej analizy tekstu. W części empirycznej wskazano na możliwości zastosowania techniki text mining do monitorowania nastrojów i sposobu postrzegania marki przez klientów w segmencie B2C przy wykorzystaniu danych pochodzących z serwisów internetowych.

S ł o w a k l u c z o w e: text mining, dane tekstowe, marka, internet, wizerunek marki, R, twitter

Klasyfikacja JEL: L29

* Adres do korespondencji: Joanna Michalak, Wyższa Szkoła Bankowa w Toruniu Wydział Finansów i Zarządzania, ul. Młodzieżowa 31a, 87-100 Toruń, e-mail: michalak@doktorant.umk.pl. 


\section{WSTĘP}

Przez Internet w stronę przedsiębiorstwa wysyłany jest szereg sygnałów a prawidłowa ich interpretacja może przyczynić się do identyfikacji potrzeb potencjalnych konsumentów. Dane z social media mogą dotyczyć m.in. następujących parametrów: liczba fanów, dotarcie, liczba udostępnień, ocena wydźwięku, polubienia. $Z$ drugiej strony pozostaje szereg opinii generowanych niezależnie przez tzw. liderów opinii bądź innych internautów (określani są oni jako naturalni ambasadorowie działań marketingowych przedsiębiorstwa) [www.imm.com.pl/monitoring_social_media]. Umiejętne wykorzystanie możliwości, jakie daje monitorowanie wydźwięku ich opinii, pozwala na kontrolę i stymulowanie nastawienia internautów do marki. Codziennie w sieci w czasie rzeczywistym i ciągłym generowane są terabajty danych tekstowych, ogólny zbiór tych danych jest nieprecyzyjny i obarczony dużymi zniekształceniami i zakłóceniami. Techniką umożliwiającą wydobycie informacji z dużych tekstowych baz danych jest text mining.

W pracy postawiono tezę: wykorzystanie danych tekstowych może przyczynić się do zwiększenia efektywności i kontroli w procesie budowania marki i jej wizerunku. Część teoretyczna opracowania dotyczy krótkiego przeglądu głównych obszarów text mining, część empiryczna wskazuje na możliwość wykorzystania górnictwa tekstu w celu identyfikacji w dużych zbiorach danych tekstowych informacji przydatnych do ekstrakcji wzorców związanych z postrzeganiem marki przez pryzmat wypowiedzi konsumentów na blogach, forach i portalach społecznościowych.

\section{WIZERUNEK MARKI}

Marki stanowią silną i ważną część kultury codziennej i świata biznesu [Kotler i in., 2008, s. 7-10] „Marka jest nazwą, symbolem, terminem, wzorem, znakiem graficznym lub ich kombinacją stworzoną w celu oznaczenia i odróżnienia dóbr i usług jednego przedsiębiorstwa od innych" [Kall i in., 2006, s. 20-21]. Nazwa, marka, logo, symbol i inne cechy charakterystyczne wyróżniające produkt to elementy marki. Definicja AMA nie odwołuje się jednak do tego obszaru, który akcentują praktykujący menedżerowie, czyli skojarzenia, jakie generują marki w świadomości konsumentów. Wizerunek marki to pewne wyobrażenie, zbiór przekonań o przedsiębiorstwie wykreowany w świadomości konsumentów [Kotler i in., 2008, s. 7-10]. 
Inaczej ujmując silne marki generują pewne pomysły, percepcje, oczekiwania i skojarzenia, które są wykreowane przez przedsiębiorstwo, a posiadające swoje odzwierciedlenie w umysłach konsumentów [Kall i in., 2006, s. 25-30]. Przedsiębiorstwa i korporacje przez markę składają pewną obietnicę, do której realizacji się zobowiązują. Dobrze wykreowana i zarządzana marka informuje konsumenta o korzyściach i wartościach, jakie zapewnia produkt, i pomaga w procesie podejmowania decyzji o jego zakupie. Silna marka to inaczej zrozumienie potrzeb swoich konsumentów, stworzenie intensywnych i ciekawych skojarzeń związanych z wizerunkiem marki. Już przez samo sformułowanie „silna marka” w świadomości konsumentów pojawiają się skojarzenia z produktami bądź usługami, m.in. Coca-Cola, Apple, Google, Amazon.com, Procter and Gamble etc. Tabela 1 prezentuje czołówkę najsilniejszych marek. Szczególną uwagę należy zwrócić na kolumnę brand value. Wycena wartości marki w dużym stopniu zależy od jej wizerunku, dlatego większość firm poświęca marce szczególną uwage [markana.pl/na-czym-polega-wycena-wartosci-marki-w-rankinguwartosci-marek-wielkopolski]. Dlaczego tak się dzieje? Główne czynniki to zdolność wpływania przez markę na preferencje konsumentów oraz przekonanie (też potencjalnych inwestorów) o pewności i solidności przedsiębiorstwa.

Tabela 1. Ranking najpopularniejszych marek za rok 2015

\begin{tabular}{|c|c|c|c|}
\hline L.P. & Brand & Brand Value \$M & Brand Value Change 2015 vs 2014 \\
\hline 1 & Apple & 246,992 & $67 \%$ \\
\hline 2 & Google & 173,652 & $9 \%$ \\
\hline 3 & Microsoft & 115,5 & $28 \%$ \\
\hline 4 & IBM & 93,987 & $-13 \%$ \\
\hline 5 & VISA & 31,962 & $16 \%$ \\
\hline 6 & at\&t & 89,492 & $15 \%$ \\
\hline 7 & VERIZON & 86,009 & $36 \%$ \\
\hline 8 & Coca-Cola & 83,841 & $4 \%$ \\
\hline 9 & Mcdonald's & 81,162 & $-3 \%$ \\
\hline 10 & Marlboro & 80,835 & $19 \%$ \\
\hline
\end{tabular}

Źródło: www.millwardbrown.com/BrandZ/2015/Global/2015_BrandZ_Top100_ Chart.pdf 
W sytuacji nasycenia rynku produktami i usługami, które posiadają niemalże identyczne wartości funkcjonalne akcentowanie znaczenia marki i jej wizerunku jest istotne nie tylko z punktu widzenia przedsiębiorcy, ale również konsumenta dla którego niewątpliwe korzyści to m.in. obniżenie kosztów związanych z poszukiwaniem produktu bądź możliwość identyfikacji z pewnymi wartościami i ideami, jakie kreuje marka. Zarządzanie marką i jej wizerunkiem jest trudne, szczególnie w przypadku silnych marek, które od lat są liderami w swojej branży, należy bowiem pamiętać, że chociaż przedsiębiorstwa wprowadzają impuls do kreowania marki (poprzez programy marketingowe i inne działania), to marka jest czymś, co jest silnie zakorzenione w umysłach konsumentów, a każde nowe działania bądź zmiany porównywane są z tą ściśle zindywidualizowaną świadomością marki, jaka już istnieje. Świadomość marki to jeden z elementów najczęściej podlegających badaniu, podczas którego sprawdzany jest spontaniczny stopień znajomości danej marki wśród uczestników badania. Jednak w pełni niewykorzystanym źródłem obszernych danych dotyczących postrzegania marki jest internet, duża ilość danych w postaci tekstowej generowanych przez użytkowników jest swobodnie dostępna na portalach społecznościowych, forach tematycznych, blogach, etc. Dane te są nieustrukturyzowane $\mathrm{i}$ trudne do oceny, jednak informacje $\mathrm{z}$ nich wydobyte mają dużą wartość biznesową. Dla przykładu: każda zmiana dotycząca wybranego elementu marki (logo, nazwa) może być oceniana w portalach społecznościowych, tym samym kluczowe jest wydobycie ogólnego nastawienia i opinii, co daje przedsiębiorstwu możliwość kontroli. Celem opracowania jest wskazanie możliwości zastosowania techniki text mining do monitorowania nastrojów i sposobu postrzegania marki przez klientów w segmencie B2C. Badanie prowadzone jest dla marek wyszczególnionych w tabeli 1, ze względu na ramy objętościowe w opracowaniu zostanie przedstawiony tylko fragment analizy dla marki Coca-Cola.

\section{TEXT MINING}

Rozwój technik umożliwiających wydobycie informacji z danych tekstowych (niestrukturalnych, semistrukturalnych oraz w pełni zorganizowanych) [Tan, 1999, s. 65-70] jest tematem ciągle podejmowanym głównie ze względu na dwa czynniki:

1. $80 \%$ danych $\mathrm{w}$ przedsiębiorstwach stanowią dane tekstowe [Tan, 1999, s. 65-70]. 
2. Rozwój internetu, wzrost znaczenia mediów społecznościowych i ich rolę opiniotwórczą [Berry Kogan, 2010, s.15].

Pociąga to za sobą wzrost popytu (zarówno w środowisku akademickim, jak i przemyśle) na rozwój systemów i algorytmów umożliwiających ekstrakcję informacji z danych tekstowych. Początek popularności text mining przypada na lata 90. XX wieku [Lula, 2005, s. 68], na szczególną uwagę zasługuje w tym czasie praca Martina A. Hearst [Hearst, 1999], w której text mining, inaczej eksploracja tekstu, definiowana jest jako proces mający na celu wydobycie z zasobów tekstowych nieznanych wcześniej informacji. $\mathrm{Na}$ bazie tych informacji formułowane są wnioski użyteczne zarówno w procesie podejmowania decyzji, jak i kontroli dotychczas podjętych działań w przedsiębiorstwie. Technika ta ciągle ewoluuje i ma charakter interdyscyplinarny z pogranicza: data mining, uczenia maszynowego, przetwarzania języka naturalnego, lingwistyki, statystyki oraz informatyki.

Źródłem danych tekstowych może być zarówno wnętrze organizacji (dokumentacja, notatki służbowe), jak i jej otoczenie (wypowiedzi konsumentów na forach, blogach i w social mediach). Dane tekstowe charakteryzują się różnym stopniem standaryzacji, uporządkowaniem oraz skomplikowaniem. Ze względu na dużą liczbę dokumentów, które przechowywane są w różnych formatach, wydobycie użytecznej informacji z tekstu jest czynnością bardziej skomplikowaną niż w przypadku danych ilościowych. Zbiory danych tekstowych są często nieustrukturyzowane oraz rozmyte. Obecnie większość analiz tekstu ukierunkowana jest nie na znaczeniu wyrazów czy zdań (treści semantycznej), ale reguł i prawidłowości związanych z występowaniem określonych ciągów znaków [Gładysz, 2012, s. 643-651], co jest czynnością prostszą ze względu na specyfikę analizowanych danych.

\subsection{ZASTOSOWANIA TEXT MINING}

Spektrum zastosowań text mining jest szerokie [Drelichowski i in., 2013; Gluczyńsk, 2004; Drelichowski i in., 2012; Morzy, 2004]. Poniżej wyszczególniono najważniejsze obszary zastosowań text mining [Lula, 2005, s. $68-71]$ :

- pozyskiwanie informacji z dokumentów: systemy wspierania działalności biznesowej ukierunkowane są na pozyskanie informacji bazującej przede wszystkim na próbie dopasowania do poszczególnych 
fragmentów tekstu wzorców określających rodzaj poszukiwanych treści, najczęściej spotykanym wzorcem są słowa kluczowe;

- identyfikację wiadomości zawierających określone treści: system monitoruje dużą liczbę dokumentów w celu wyodrębnienia tych, które pasują do wcześniej zdefiniowanego kryterium;

- klasyfikację wzorcową: w tym przypadku analizowane są zbiory dokumentów, ze względu na zawarte w nich informacje dokumenty te zostają przyporządkowane do klas na bazie wcześniej zdefiniowanego wzorca oraz sposobu identyfikacji podobieństwa dokumentów do wzorca;

- klasyfikację bezwzorcową: wydzielane są grupy dokumentów podobnych do siebie (ważnym zadaniem jest tutaj wyznaczenie cech charakterystycznych dla dokumentów, które wchodzą w skład poszczególnych skupień);

- wykrywanie związków istniejących pomiędzy informacjami pozyskiwanymi z danych tekstowych bądź identyfikowanie dokumentów, które są ze sobą powiązane (ze względu na zawarte w nich treści);

- wizualizacja;

- generowanie streszczeń;

- wydobywanie wiedzy o trendach i relacjach (występujących pomiędzy ludźmi, organizacjami lub miejscami);

- weryfikacja nastawienia konsumentów do oferowanych przez przedsiębiorstwo dóbr i usług, inaczej analiza sentymentu bądź eksploracja opinii: text mining pozwala lepiej zrozumieć postrzeganie pozycji produktów danego przedsiębiorstwa wobec produktów konkurencji, analizę zmiany nastawienia do produktu w czasie realizacji działań marketingowych, wykorzystywanie pozytywnych opinii w celu komunikacji ich dalej, szybką identyfikację potrzeb klientów [g1.computerworld.pl/cw/pdf/bigdata/Text_Mining.pdf].

Należy pamiętać, że istotą text mining jest prostota interpretacji oraz użyteczność uzyskanych wyników. Istotne jest odkrywanie nowych informacji, które łączone są później ze sobą w fakty i hipotezy.

\subsection{ZEWNĘTRZNE ŹRÓDŁA DANYCH TEKSTOWYCH}

Dane tekstowe w przedsiębiorstwie są łatwe do katalogowania i zebrania, dodatkowe trudności sprawia śledzenie piętrzących się danych w sieci, gdzie są one generowane w sposób ciągły i równoległy w „rożnych miej- 
scach". Jednym z problemów jest wybór właściwej próby, na podstawie której można przeprowadzić wiarygodny i wartościowy proces: eksploracji zjawiska, analizy i prezentacji zsyntezowanych danych. Monitorując wirtualne wypowiedzi, trudno skupić się na strukturze demograficznej, dlatego zalecane może być zawężenie obszaru poszukiwania danych do jednego bądź kilku portali. Najbardziej popularne serwisy będące źródłem danych to: Facebook, MySpace, Twitter. Automatyczne pozyskanie danych z Facebook bądź Twitter umożliwiają m.in. następujące oprogramowania: R Cran (package twitteR, package Rfacebook), Facepager [https:/github.com/ strohne/Facepager/]. Facepager jest darmowym oprogramowaniem, które umożliwia automatyczne pozyskanie publicznie dostępnych danych, m.in. z Facebooka i Twittera. Wszystkie dane są przechowywane w bazie danych SQLite database i mogą być eksportowane do pliku CSV.

Procedura w programie polega na stworzeniu nowej, pustej bazy danych („New Database”), do której zapisywane będą pozyskane wiadomości. W ramach tej bazy dodawane są kolejne węzły („Add Nodes”). Importowanie danych z Twittera możliwe jest po uzyskaniu tzw. Access Token oraz Access Token Sectret, niewątpliwą zaletą w porównaniu do wykorzystania pakietów dostępnych w oprogramowaniu $\mathrm{R}$ jest automatyczne uzyskanie dostępu wyłącznie dzięki logowaniu do własnego konta przez wewnętrzne okno logowania, wywołane przez przycisk „Login to Twitter” [rys. 1b]. Użytkownik musi dodatkowo sprecyzować zasoby, które chce pozyskać (tutaj: serach/tweets) oraz nadać dodatkowe parametry wyszukiwania (tutaj: następuje wyszukiwanie wiadomości wyłącznie w języku angielskim [„,en”] odnoszących się do frazy „cola”). Niestety oprogramowanie zawiera ograniczenia w pobieranych wiadomościach do tych, które zostały zamieszczone w czasie wywołania polecenia, jednak istnieje możliwość ustawienia czasu pobierania z zadanym interwałem pomiędzy kolejnymi wyszukiwaniami. 


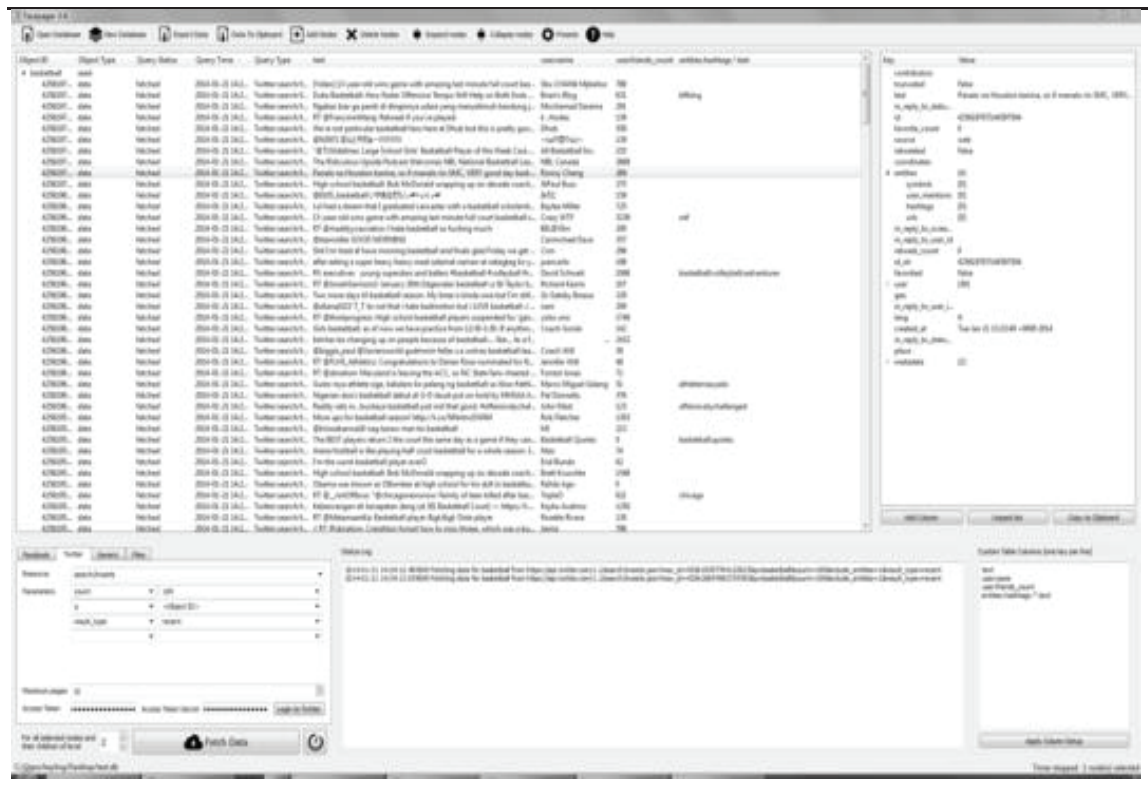

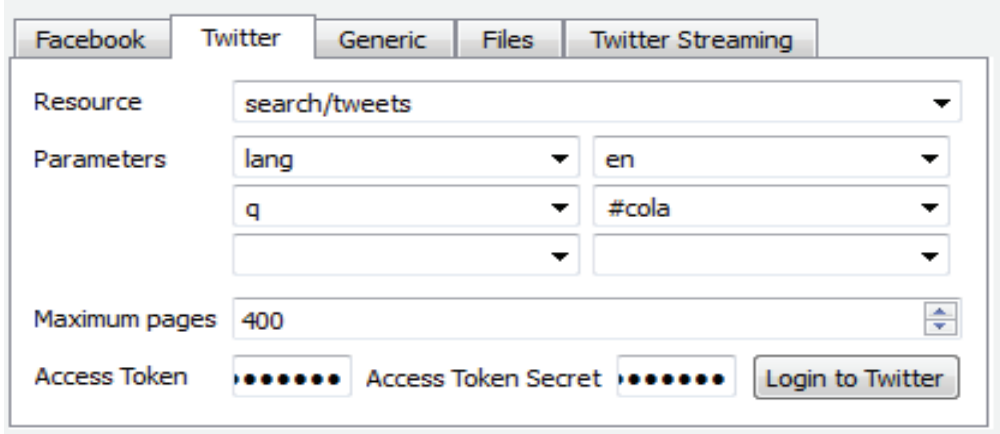

Rysunek 1. Panel główny programu Facepager 3.6 [a] okno główne, [b] ustawienia kryteriów wyszukiwania wraz z modułem logowania do portalu Twitter

Źródło: http://www.ls1.ifkw.unimuenchen.de/personen/wiss_ma/keyling_till/software. html.

\subsection{PRZYGOTOWANIE DANYCH W PROGRAMIE R CRAN}

R jest pakietem statystycznym, udostępnianym na zasadzie wolnego oprogramowania, które jest dynamicznie rozszerzane przez użytkowników. 
Ze względu na ramy objętościowe nie ma możliwości zaprezentowania całego spektrum zagadnień związanych z techniką text mining w oprogramowaniu R, dlatego zademonstrowano tutaj jedynie kilka przykładów. Pierwszą z czynności, która poprzedza właściwą analizę jest przygotowanie tzw. korpusu danych, czyli części oczyszczonej ze zbędnych elementów, które zniekształcają i utrudniają analizę tekstu. Poniżej przedstawiono kod przedstawiający wstępne przygotowaniem danych, $\mathrm{tj}$. czyszczeniem bazy danych, zamyka się on w 4 podstawowych krokach.

\#załadowanie biblioteki do środowiska $R$

library $(\mathrm{tm})^{1}$

\#załadowanie danych do środowiska $R$, pozyskano tekst celowo w języku angielskim ze względu na ułatwienia zwiazane z dalszą obróbka danych (dane<-VCorpus(DirSource(,ścieżka do pliku”, encoding=,UTF-8”), readerControl = list(language $=$ "en"))

\# Krok 1: usunięcie z tekstu tzw. białych znaków, czyli symboli, które sq używane $w$ tekście i nie posiadaja swojej reprezentacji graficznej. Przykładem takiego znaku jest spacja, tabulacja czy znak przejścia do nowej linii

dane_oczyszczone $<$-tm_map(dane, stripWhitespace)

\# Krok 2: Konwersja na małe litery

dane_oczyszczone<-tm_map(dane_oczyszczone, cotent_transformer(tolower))

\# Krok 3: usunięcie z tekstu tzw. stopwords, czyli najczęściej występujących słów w danym języku; słowa te są tzw. „,zapychaczami treści” i nie niosą za sobą żadnej wartości merytorycznej

dane_oczyszczone<-tm_map (dane_oczyszczone, removewords, stopwords (,english")

\# Krok 4: redukcja do rdzenia, czyli wydobycie z wybranego wyrazu tzw. rdzenia, a więc tej jego części, która jest odporna na odmiany przez przyimki, rodzajniki itp.

dane_oczyszczone<-tm_map(dane_oczyszczone, stemDocument)

1 Szersze omówienie możliwości, jakie daje praca na pakiecie TM, znajduje się pod adresem: https://cran.r-project.org/web/packages/tm/index.html. 


\section{PRZYKŁAD EMPIRYCZNY}

W opracowaniu za przykład przyjęto Coca Cola Company. Wybór ten podyktowany był pozycją przedsiębiorstwa na rynku napojów gazowanych i rozpoznawalnością marki. Pozyskane dane pochodzą głównie z forów internetowych oraz Twittera. Analiza została przeprowadzona w programie R przy użyciu pakietów: TM, WORDCLOUD. Analizę sentymentu przeprowadzono za pomocą aplikacji Tweet Sentiment Visualization [www.csc.ncsu.edu/faculty/healey/tweet_viz]. Niestety większość darmowych platform zakłada ograniczenia $\mathrm{w}$ postaci ilości analizowanego tekstu.

Opracowanie ograniczyło się do podstawowej analizy tekstu związanej z wyszukiwaniem słów kluczowych, określeniem związku pomiędzy zwrotami słów (na bazie współczynnika korelacji) oraz wydźwiękiem emocjonalnym. Analiza związana z postrzeganiem marki powinna być bowiem ukierunkowana na poznanie tych cech produktów, które wpływają na zadowolenie klienta oraz cech wywołujących złe wypowiedzi (również w odniesieniu do prowadzonych kampanii bądź akcji charytatywnych). 


\section{TWEET SENTIMENT VISUALIZATION ${ }^{2}$}

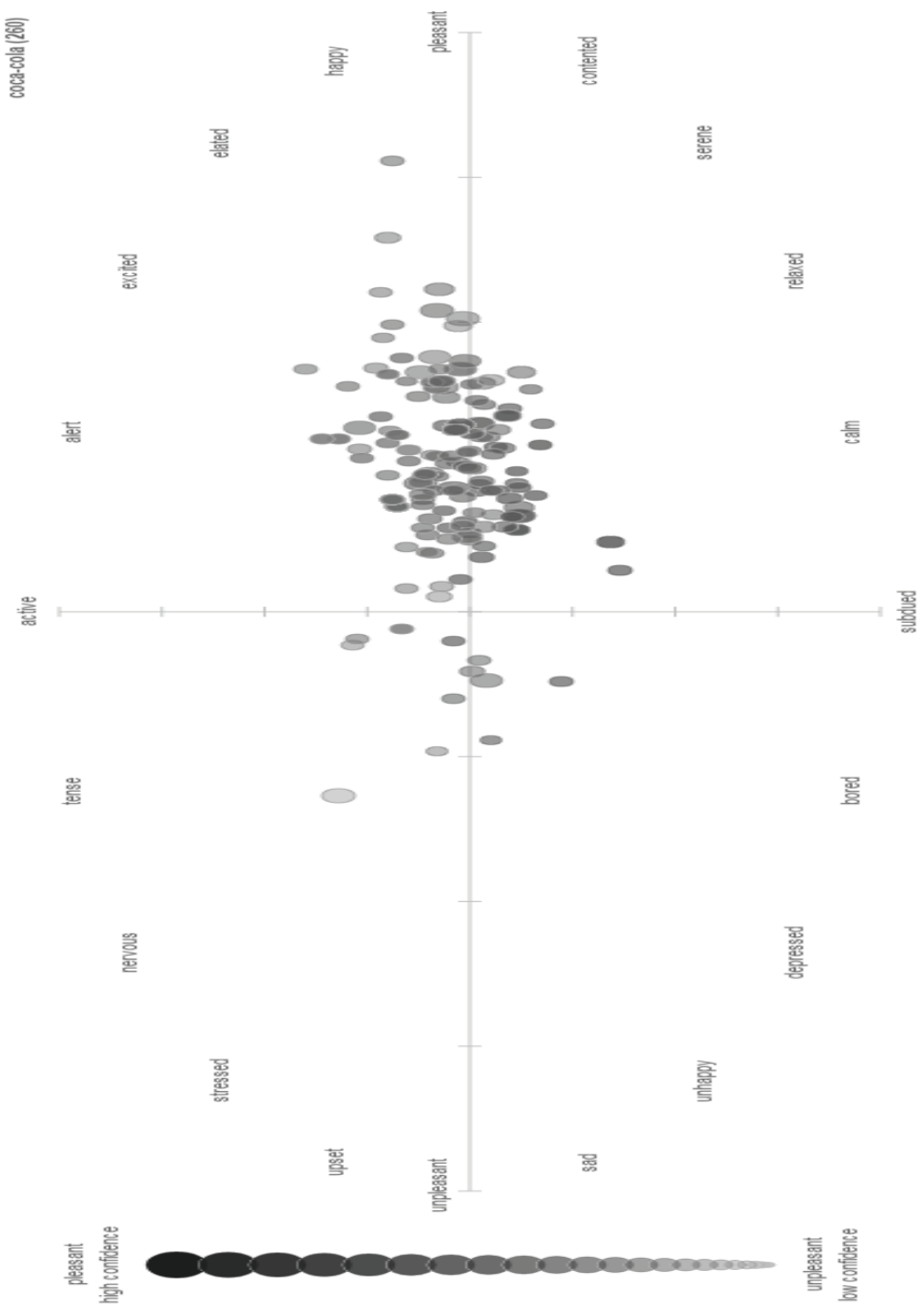

Rysunek 2. Emocjonalny wykres punktowy wypowiedzi z portalu Twitter dla frazy \#coca-cola [n=260]

Źródło: www.csc.ncsu.edu/faculty/healey/tweet_viz/tweet_app/.

2 Dokładny opis formalnej oprawy danych został pominięty ze względów objętościowych opracowania. 

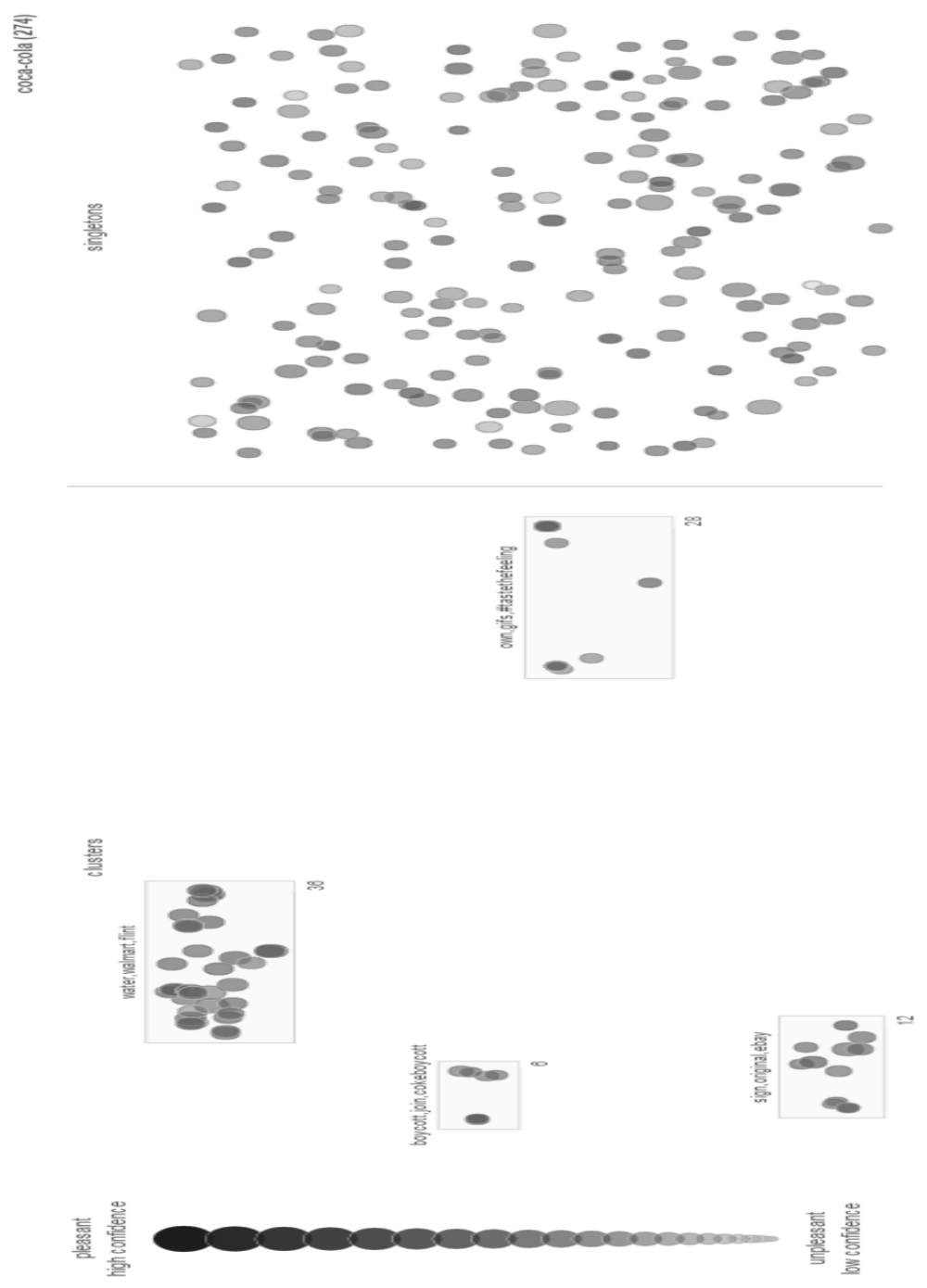

Rysunek 3. Klasyfikacja (według słów kluczowych) wypowiedzi wyszukanych dla frazy \#cola-cola [ $\mathrm{n}=274]$

Źródło: www.csc.ncsu.edu/faculty/healey/tweet_viz/tweet_app/. 

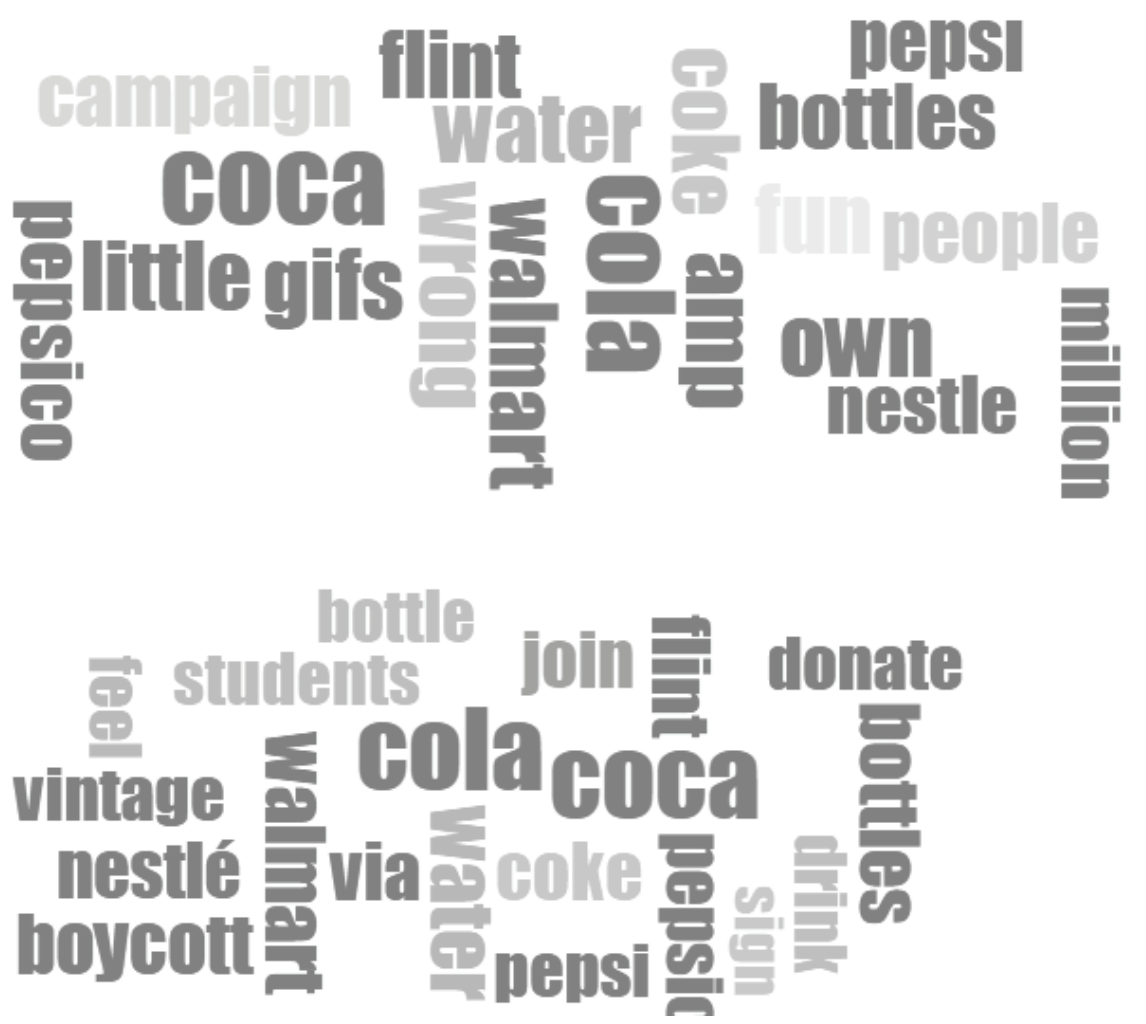

Rysunek 4. Wizualizacja Tag Cloud wygenerowana z wypowiedzi o pozytywny wydźwięku

Źródło: opracowanie na stronie: https://www.csc.ncsu.edu/faculty/healey/tweet_viz/ tweet_app/.

\section{TEXT MINING W PROGRAMIE R}

Tabela 2. Najczęściej występujące słowa w analizowanej bazie tekstowej

\begin{tabular}{|c|c|c|c|c|c|c|c|c|c|}
\hline Słowo & drink & can & Like & One & just & will & company & taste & look \\
\hline częstość & 118 & 79 & 79 & 72 & 70 & 70 & 64 & 46 & 56 \\
\hline
\end{tabular}

Źródło: opracowanie własne w programie R (pakiet tm). 


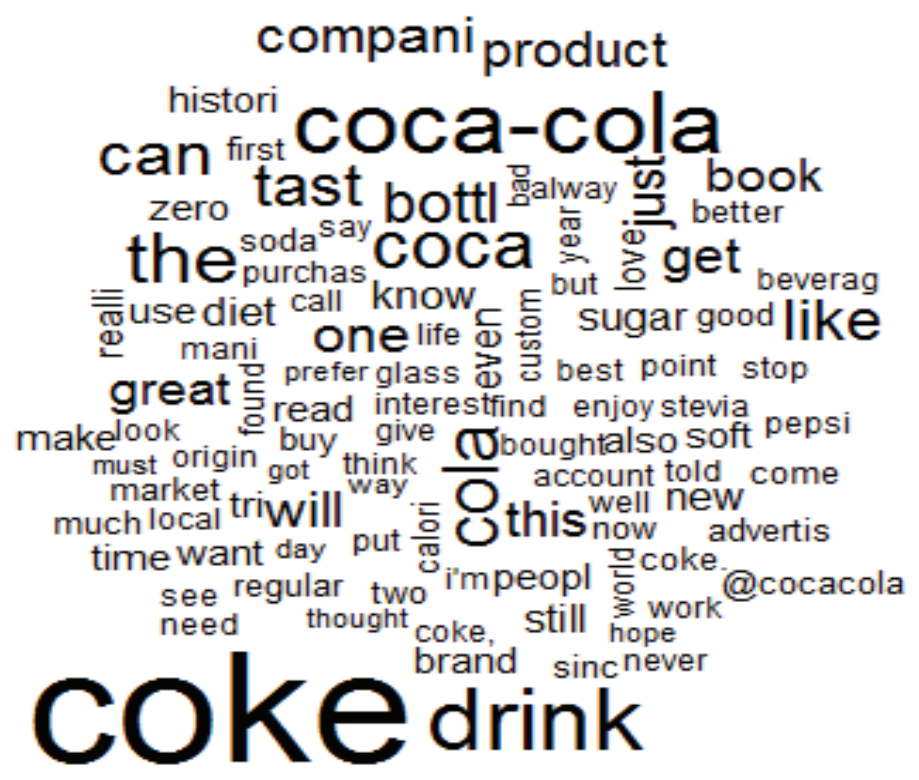

Rysunek 5. Word Cloud dla 100 najczęściej występujących słów w wypowiedziach konsumentów

Źródło: opracowanie własne w programie R (pakiet wordcloud).

Tabela 3. Lista słów najwyżej skorelowane ze słowem „drink”

\begin{tabular}{|c|c|c|c|c|}
\hline Słowo & need & prefer & hot & feel \\
\hline współ. korelacji & 0.91 & 0.89 & 0.89 & 0.88 \\
\hline Słowo & soft & love & Origin & expens \\
\hline współ. korelacji & 0.82 & 0.81 & 0.81 & 0.84 \\
\hline
\end{tabular}

Źródło: opracowanie własne w programie R (pakiet wordcloud).

\section{INTERPRETACJA}

- Wizualizacja nastrojów na postawie częstości słów (rysunek 2) kieruje ogólny wydźwięk wypowiedzi w kierunku nastrojów: „happy”, „pleasant”, „excited”. Dana treść [n=260] ma niewątpliwie charakter pozytywny. Marka uzyskuje wysoki poziom pozytywnych opinii. W takich przypadkach prowadzenie przez przedsiębiorstwo dalszych działań na 
portalach społecznościowych powinno skupić się na podtrzymywaniu tych tendencji.

- Podział zbioru na grupy wypowiedzi podobnych do siebie (rysunek 3) pozwolił na wyszczególnienie trzech głównych grup.

1) Grupa 1, tematyka wypowiedzi: Walmart, Flint. Dotyczy to akcji charytatywnej, w której uczestniczy Coca-Cola Company [www.forbes.com/sites/clareoconnor/2016/01/26/walmart-pepsi-coca-cola-nestle-donate-6-5m-bottles-of-water-to-flintmich-students/\#104a682f433f]

2) Grupa 2, wypowiedzi pod tagiem \#tastethefeeling (jest to nowa, globalna kampania dla wszystkich marek Coca-Cola [www. cocacola.com.pl/historie/produkty/taste-the-feeling-nowaglobalna-kampania-dla-wszystkich-marek-coca-cola/].

Kampania podkreśla zarówno funkcjonalny, jak i emocjonalny kontakt z Coca-Colą.

3) Grupa 3, wypowiedzi użytkowników, dla których nie można wyznaczyć wspólnego wzorca.

Dokładny przegląd treści potwierdził pozytywny charakter wypowiedzi we wszystkich 3 grupach. Słowa użyte w analizowanych wypowiedziach koncentrują się wokół emocji (radości, zabawy) i smaku. Produkty marki przeważnie są związane z następującymi czynnościami: zabawa, posiłek, spotkania ze znajomymi. Jak widać prowadzone przez przedsiębiorstwo działania oceniane są na bieżąco na portalu, a dzięki dogłębnym wizualizacjom uzyskane wnioski mogą posłużyć do ich kontroli.

- Analiza częstości słów w tekście (tabela 2) pozwala wnioskować, że najczęściej wypowiedzi i oceny dotyczą: smaku, wyglądu, przedsiębiorstwa.

- Dla przykładu wyszczególniono również słowa najczęściej skorelowane ze słowem ,,drink”, na uwagę zasługuje słowo „,need” (współ. korelacji przekracza poziom 0.9). Pośrednio może to wskazywać na niezwykłą skuteczność działań marketingowych przedsiębiorstwa, które podtrzymuje potrzebę konsumpcji swoich produktów.

\section{PODSUMOWANIE}

W opracowaniu przedstawiono technikę text mining, scharakteryzowano dane tekstowe, metody pozyskania i analizy tekstowych zasobów firmy. Wskazano na ogromny potencjał związany z analizą danych tekstowych. 
Przeprowadzona analiza pozwoliła na ocenę wypowiedzi użytkowników Twitter dotyczących marki Coca-Cola. Ich ogólny wyraz emocjonalny jest pozytywny. Przedstawione opracowanie można traktować jako wprowadzenie do pełnej analizy danych tekstowych, porównania marek i wykorzystania danych z portali społecznościowych. Analiza może dostarczyć użytecznych i przejrzystych informacji na potrzeby zarządzania wizerunkiem marki. Opracowanie będzie rozszerzane w dalszych badaniach.

\section{LITERATURA}

Berry, M. W., \& Kogan, J., (2010), Text mining: applications and theory. John Wiley \& Sons.

Drelichowski L., Siwiec J., (2012), Application of text mining for analysis and knowledge clustering Publisher in scientific journal studies and proceedings of the Polish Association for Knowledge Management, PSZW, z. 58, Bydgoszcz.

Drelichowski L., Zwierzchowski D., (2013), Zastosowanie text mining do analizy struktury treści artykułów polskojęzycznych publikacji , Studia i Materiały” polskiego stowarzyszenia zarzadzania wiedza [online]: www.pszw.edu.pl/ images/publikacje [05.01.2016].

Feinerer I. (2008), An Introduction to Text Mining in R, „R News”, No. 8(2), s. 19-22, [online] http://CRAN.R-project.org/doc/Rnews/ [05.01.2016]

Gładysz A., Zastosowanie metod eksploracyjnej analizy tekstu w logistyce., Logistyka No 3, 2012, s. 643-651 [online] http://www.czasopismologistyka.pl/ [19.12.2015]

Gulczyński M. (2004), Techniki ,odkrywania wiedzy” (data mining) oraz ich zastosowania, Zeszyt nr 2 Studia i Materiały, PSZW, Bydgoszcz.

Hearst M. A. (1999), Untangling Text Data Mining, Proceedings of ACL'99: the 37th Annual Meeting of the Association for Computatonal Linguistic, University of Meryland, June 20-26, 1999 (invited paper) [online] www. sims.berkley.edu/ hearst/papers/ac199/ac199-tdm.html [06.12.2015]

Kall J. Kłaczek R. Sagan A. (2006), Zarządzanie marka, Oficyna Ekonomiczna, Kraków.

Keyling Till, Jünger, Jakob (2013), Facepager. An application for generic data retrieval through APIs. Source code available [online] https://github.com/ strohne/Facepager/ [01.12.2015]

Kotler Ph., Pfoertsch W. (2008), Zarzadzanie marka w segmencie B2B, Wydawnictwo Naukowe PWN, Warszawa. 
Lula P. (2005), Text mining jako narzędzie pozyskiwania informacji dokumentów tekstowych., [online] www.statsoft.pl/portals/0/Downloads/Text_mining jako_narzedzie_pozyskiwania.pdf [06.01.2015]

Morzy T. (2004), Odkrywanie asocjacji: Algorytmy i struktura danych, Ośrodek Wydawnictw Naukowych.

Tan A. (1999), Text Mining: The state of the art and the challenges, Pacific Asia Conference on Knowledge Discovery and Data Mining PAKDA.

\title{
ŹRÓDŁA INTERNETOWE
}

www.imm.com.pl/monitoring_social_media [24.01.2016].

markana.pl/na-czym-polega-wycena-wartosci-marki-w-rankingu-wartosci-marekwielkopolski [10.01.2016]

g1.computerworld.pl/cw/pdf/bigdata/Text_Mining.pdf [22.12.12.2015]

www.csc.ncsu.edu/faculty/healey/tweet_viz/tweet_app/ [24.01.2016].

www.csc.ncsu.edu/faculty/healey/tweet_viz [24.01.2016].

www.forbes.com/sites/clareoconnor/2016/01/26/walmart-pepsi-coca-cola-nestle-donate-6-5m-bottles-of-water-to-flint-mich-students/\#104a682f433f [24.01.2016].

www.cocacola.com.pl/historie/produkty/taste-the-feeling-nowa-globalna-kampania-dla-wszystkich-marek-coca-cola/ [24.01.2016].

\section{USE OF TEXT DATA TO MONITOR MOODS AND PERCEPTIONS OF BRANDS IN THE CASE OF SOCIAL MEDIA}

\begin{abstract}
The purpose of this paper is use text mining techniques to extract information from text data in order to use them to manage brand image. The primary objective of this study is to present an exploratory analysis of the text. In the empirical part pointed out the possibility of applying text mining techniques to monitor moods and perception of the brand using data from websites.
\end{abstract}

Keywords: text mining, text data, brand, internet, R, twitter 